\title{
The Problems of Implementing the Bologna Process in the Higher Education System of Uzbekistan
}

\author{
Zukhra Abdikarimova \\ Department of Professional Education, Tashkent State University of Economics, Tashkent, Uzbekistan \\ Email address: \\ venus_0204@mail.ru

\section{To cite this article:} \\ Zukhra Abdikarimova. The Problems of Implementing the Bologna Process in the Higher Education System of Uzbekistan. International \\ Journal of European Studies. Vol. 3, No. 1, 2019, pp. 23-26. doi: 10.11648/j.ijes.20190301.14
}

Received: February 28, 2019; Accepted: March 1, 2019; Published: May 6, 2019

\begin{abstract}
Globalization processes can be seen in the system of socio-economic relations worldwide. These processes, including the higher education system, focus on increasing the effectiveness of education, supporting international coverage of education, and, most importantly, the use of modern methods of modernizing higher education. The article examines the current state of the Higher Education in Uzbekistan and the role of Bologna Process to create innovative environment in Higher Education System of Uzbekistan. In addition, problems related to the implementation of this process in the higher education system are discussed. As well as, the further reforms are given to eliminate those problems.
\end{abstract}

Keywords: Higher Education, Bologna Process, Diploma Supplement, Credit System, Quality of Education, Mobility, Qualification

\section{Introduction}

The area of researches in the 21 st century now requires a holistic view of the events. Such high trends and internationalization in science and education provide an opportunity to learn more about specific areas of qualification system and other relevant research areas. This is one of the most important factors to build a knowledge-based and sustainable economy [1].

Bologna process shows particular importance to implement these goals. The Bologna process is now being expanded to 48 countries, of which 28 are EU countries and the remaining 20 are non-EU countries. In addition, 23 countries have been registered as observers in the Bologna process. At present, seven of the 11 CIS countries are members of the Bologna Declaration: Russia, Ukraine, Azerbaijan, Armenia, Moldova, Belarus and Kazakhstan. In other countries, the Bologna process is actively discussed and its peculiarities and the use of these principles in different countries are carefully studied. A high level of quality can be observed in the education system of countries where the Bologna process is successfully implemented [2].

On October 24, 2018, President of Uzbekistan Shavkat Mirziyoev denominated the higher education of the country as overdue in the meeting on higher education. Currently, there are 91 institutions in the higher education system of Uzbekistan. Programs of higher education are provided by 2 academies, one conservatory, one higher professional school, 23 universities, 33 institutes, 20 local institutes of higher education and 11 branches of foreign higher educational institutions. In addition, 13 higher education institutions will be planned to open in 2019. It is so miserable that while higher education institutions are extensive, none of them has a decent position on the international rankings of higher education. The President of Uzbekistan emphasized the issues of promoting the prestige of higher education institutions and their professors in the international community and involvement of world-renowned scientists, highly-qualified researchers and teachers in the educational process [3].

The joining of Uzbekistan to the Bologna processes is crucial to train highly qualified cadres, support for the intellectual capabilities of the staff, the internalization of higher education and its adaptation to international standards and, in general, the extensive reforms in the educational process in the future. But, some problems are seen to implement the Bologna process in the higher education system of Uzbekistan. To tackle these problems helps to promote quality and competitiveness of the higher education system of Uzbekistan [4-5]. 


\section{Method}

The Bologna process was based on the 1998 agreement signed by representatives of four European Union countries: France, Germany, Italy, and the United Kingdom. Education ministers from Bologna process met 10 times during the period between 1998 and 2018. As a result of those meetings, Bologna process programs and objects have widened.

Bologna Process increases opportunities for study abroad because of the availability of educational programs in several countries. As a result of the exchange of knowledge within the students, staffs, they will be able to develop their own worldview. This will help them become stronger candidates in their job arenas in the future.

Adaptation of Uzbekistan to the Bologna process is a key priority in modernizing higher education system of the country. It plays an important role in promoting international co-operation and improving the quality of education [6].

The technical aspects of integration into the process, the formation and implementation of Bologna process principles should be learned deeply to create innovative approaches to modernization of higher education system of Uzbekistan through the Bologna process. Firstly, it is important to adapt national education system structure to the Bologna process and implement requirement of main principles of bologna process. The main principles of the Bologna process are the directions for the countries to rebuild the Higher Education System. These principles cover the 3 cycles of learning process (bachelor, master and doctorate) [7].

Main principles of Bologna process:

1. Diploma Supplement;

2. ECTS (European Credit Transfer System);

3. Three-tier system of higher education;

4. Academic mobility;

5. Quality assurance of higher education;

The adaptation of a simplified and similar level of education through the Diploma Supplement enhances the international competitiveness of the European higher education system and the employment of European citizens. Diploma Supplement is a form of document that is provided to each graduate as a qualification, describing the education system of the country, the program in the educational institution, and the main directions studied within the framework of the program.

The Diploma supplement serves to enhance international recognition of academic and professional qualifications. Basically, most of the Bologna countries the diploma supplement is given not only in the national language but also "widely spoken" language according to requirement of the students.

In Uzbekistan, a diploma supplement for graduates of higher education institutions is now available, but it should be acknowledged that this type of diploma supplement is not correspondent to the diploma supplement in the higher education system of Bologna countries.

Table 1. Diploma Supplement of Bologna countries and Uzbekistan.

\begin{tabular}{|c|c|}
\hline Bologna countries & Uzbekistan \\
\hline $\begin{array}{l}\text { Information identifying the holder of the qualification } \\
\text {-family name } \\
\text {-given name } \\
\text {-date (place, country) of birth } \\
\text {-Student identification number } \\
\text { Information identifying the qualification }\end{array}$ & $\begin{array}{l}\text {-family name } \\
\text { - given name }\end{array}$ \\
\hline $\begin{array}{l}\text {-Name of the credential, and, if applicable, any nationally recognized title } \\
\text { that comes with it, both in the original language. The major field of study. } \\
\text {-Name of the institution awarding the credential, its status (e.g. private, state) } \\
\text { - Language (s) of instruction and examination. } \\
\text { Information on the level of the credential }\end{array}$ & $\begin{array}{l}\text {-The name of the institution } \\
\text {-Status of the institution awarding the credential, (e.g. private, state). Most } \\
\text { of the universities belong to state that's why "state" is used as a status. } \\
\text {-The direction of education }\end{array}$ \\
\hline $\begin{array}{l}\text {-Given the range of tertiary awards in different European countries, the } \\
\text { precise level of the credential in the national structure of education (for } \\
\text { which a schematic is attached. } \\
\text {-Requirements for entry to the program in which the credential is granted. } \\
\text {-The official length / duration of the program. }\end{array}$ & no \\
\hline Additional information. & $\begin{array}{l}\text { no } \\
\text { no }\end{array}$ \\
\hline
\end{tabular}

It should be noted that the diploma supplement of graduates in Uzbekistan is only in the state language (The Uzbek language). That's why most of the students face difficulties if they want to continue their study in foreign countries. If they want to study abroad, first of all, they need to be translated their diploma supplement then they need to be confirmed it. Obviously, this process demands much time and a lot of expenses. In this case, it is important to adapt the diploma supplement to foreign standards and introduce the English version of the diploma supplement, too. We consider, it should be implemented according to requirement of each graduates. Because, some of the 
students want to continue their study and other has already had workplace. As well as, it should be thought deeply about provision of diploma supplement whether it is free or graduates have to pay [8].

On the other hand, most of the graduates are required a sheet about statement of the purpose and function of the credential when they work at a certain workplaces. In that case, it is difficult to find out information and it causes spending time and other trouble [9-10].

\section{Results}

The three-cycle education process consists of the undergraduate and graduate stages and the transition to the second stage requires the successful completion of the first phase. In the early years of the Bologna process, the form of education was two-step, and after Berlin meeting in 2003, the doctorate was added as third cycle. The first stage of the Bologna program requires a minimum 3 years and for Masters minimum 1-2 years, and for Doctoral degree minimum 3 years. Bachelor degree in Uzbekistan is 4 years. The Master Degree is for 2 years at present. Master degree qualification is in the process of reform, and it planning to be two levels:

1. Main specialty (at least a year);

2. Scientific-pedagogical specialty (at least two years) direction can be carried out according to the theoretical knowledge and fundamental and applied research works (scientific-creative works).

In accordance with the Decree of the President of the Republic of Uzbekistan "On further improvement of postgraduate education" dated February 16, 2017, the transition to a two-tiered system of postgraduate education for a three year period has been introduced in our country. According to this, postgraduate education in Uzbekistan is awarded in two dimensions - PhD (Doctor of Philosophy) and Doctor of Science. The next issue is to revise the legislation and bring the issues of academic titles in Uzbekistan to international standards. In Uzbekistan there are just 2 academic degrees - docent and professo [11].

ECTS (European Credit Transfer System) - The European Credit Transfer System (ECTS) is aimed at increasing mobility through institutional and countrywide lending through student workload and learning outcomes. The goal of introducing a credit system is to facilitate the transparency of education and recognition of academic knowledge and qualifications.

Establishing unified loans for higher education institutions has helped to ensure mobility. This system has been successfully passed and accepted in 1989 by European Universities. Today, the European Credit System is a recognized and valid system in almost all European countries The learner is able to obtain a diploma only if he has collected the credit score. The credit system is a unit of measurement that demonstrates the achieved results, not the amount of hours spent in the learning process. That is the result-oriented unit of measurement for the specialist's level of competenc [12].

A certain number of credit units are allocated for each subject matter. ECTS is 180-240 for the bachelor's degree and 90-120 for the master's degree.

The credit education technology and the ECTS assessment system are not implemented in the higher education system of Uzbekistan student's evaluated with ranging to $56-100 \%$. This, in turn, leads to passive bilateral diploma education with European universities and a passive development of academic mobility. That is, European universities find it difficult to recognize educational outcomes in Uzbekista [13].

Quality assurance is a quality assessment of higher education, monitoring of educational process, ensuring support and improvement and the quality system of educational institutions and higher education programs. At the European level, cooperation in promoting the quality of higher education is focused on the development of common criteria and methods that help to ensure mutual confidence and recognition [14].

\section{Discussion}

On April 20, 2017 the Decree of the President of the Republic of Uzbekistan №PD 2909 "On Measures for Further Development of the Higher Education System" was adopted in Uzbekistan. The complex measures on qualitative and complete improvement of the level of education, strengthening and modernization of material and technical base, equipping them with modern educational and scientific laboratories, modern information and communication technologies have been approved by this decree. In order to improve the quality and effectiveness of the education system in Uzbekistan, on July 18, 2017 the Resolution №515 “On the organization of the State Inspectorate for Supervision of Quality of Education in the Cabinet of Ministers of the Republic of Uzbekistan" was adopted. Here, the main goal is the implementation of the state policy on control over the quality of education and training, the composition of the teaching staff, the training and qualification of the personnel in the education system.

In order to improve the quality and effectiveness of the education system in Uzbekistan, the most important goals of today's higher education institutions is to learn professional standards and employers' requirements. It is important to reexamine and regularly update curricula in the field of higher education based on market demand.

Mobility - The Bologna Process also aims to promote the movement of students, scholars and administrative staff in the European Higher Education Area. Among the European mobility programs, Tempus and Erasmus programs are of particular importance, and these programs are commonly called Erasmus $+[15]$.

The importance of mobility in ensuring quality of education is following:

Enables students to acquire extensive knowledge and skills 
on the basis of knowledge acquired from other professionals, which, in turn, influences on the ability and skills of students to succeed in a strong competitive market, and the quality of labor resources that can promote the development of national economies;

Provides researchers with new materials and expands the possibilities of organizing the results of the research work;

Increase the competence of teachers as an expert and a pedagogue in the learning process and influence the development of creative thinking.

In Uzbekistan, there are 67 projects proposed by Erasmus + Mobility Program of higher education institutions in Uzbekistan in 2017. As a result, 205 students and staff have gained experience in Europe within 35 projects in Uzbekistan.

\section{Conclusions and Suggestions}

In summary, there are a number of problems to implement the Bologna process and fulfill the requirements of the Bologna process in the higher education system of Uzbekistan. The joining of the Higher Education System of Uzbekistan to the Bologna process plays a crucial role in the development of a broad-minded specialists in the country, in the preparation of advanced specialists in various fields, in the internationalization of higher education in Uzbekistan, as well as the creation of "international ideas", adaptation of higher education to international standards, and in the modernization of the higher education system in Uzbekistan

In achieving this goal, the implementation of the following objectives will help eliminate existing problems:

1. Adaptation the diploma supplement which given graduates in Uzbekistan to the international diploma supplement and introducing the English version of the Diploma Supplement;

2. As noted above, the credit system is used in the higher education system of other countries in the European Union, as well as many other countries. In the system of higher education of Uzbekistan, it would be advisable to gradually, with deep thought, to develop a credit system in the form of an experiment on specific educational directions or specializations;

3. One of the main problems in increasing mobility is to learn foreign languages. At the same time, it should be paid attention to learn foreign languages deeply among students and professors;

4. Creating a competitive environment and achieving the quality of education through the support of a network of private higher education institutions based on publicprivate partnerships in Uzbekistan.

\section{References}

[1] Laurel S. Terry. The Bologna process and Its impact in Europe: It's so much more than degree changes.

[2] David Crosier, Teodora Parveva The Bologna Process: Its impact in Europe and beyond UNESCO: International Institute for Educational Planning.

[3] Clifford Adelman, "The Bologna Process for U. S. Eyes: Relearning Higher Education in the Age of Convergence". Institute for Higher Education Policy, 2009.

[4] Majidov, T., D. Ghosh, and K. Ruziev. 2010. Keeping Up with Revolutions: Evolution of Higher Education in Uzbekistan. Economic Change and Restructuring 43: 45-63.

[5] Pomfret, R. 2000. The Uzbek Model of Economic Development, 1991-1999. Economics of Transition 8: 733-748.

[6] Ruziev, K., and U. Burkhanov. 2016. Higher Education Reforms in Uzbekistan: Expanding Vocational Education at the Expense of Higher Education? Higher Education in Russia and Beyond 2: 14-15.

[7] Ruziev, K., D. Ghosh, and S. Dow. 2007. The Uzbek Puzzle Revisited: An Analysis of Economic Performance in Uzbekistan Since 1991. Central Asian Survey 26: 7-30.

[8] United Nations Development Programme. 2008. Education in Uzbekistan: Matching Supply and Demand. Tashkent: United Nations Development Programme.

[9] Weidman, J., and B. Yoder. 2010. Policy and Practice in Education Reform in Mongolia and Uzbekistan During the First Two Decades of the Post-Soviet Era. Excellence in Higher Education 1: 57-68.

[10] Ministry of Higher and Secondary Specialized Education of the Republic of Uzbekistan. 2013. Statistical Collection: Main Activities of the Higher Education Institutions 2012-13. Tashkent: MHSSE.

[11] Olssen, M. and M. Peters (2005) Neoliberalism, Higher Education, and the Knowledge Economy: from the Free Market to Knowledge Capitalism. Journal of Education Policy, Vol.20, No. 3, pp.313-345.

[12] Pegkas, P. and C. Tsamadias (2014) Does Higher Education Affect Economic Growth? The Case of Greece. International Economic Journal, Volume 28, No.3, pp.425-44.

[13] Pomfred, R. (2000). The Uzbek Model of Economic Development, 1991-1999. Economics of Transition. Vol. 8, pp. 733-748.

[14] Weidman, J. and B. Yoder (2010) Policy and Practice in Education Reform in Mongolia and Uzbekistan during the First Two Decades of the Post-Soviet Era. Excellence in Higher Education, Volume 1, No 1\&2, pp. 57-68.

[15] Gyimah-Brempong, K., Paddison, O. and W. Mitiku (2006) Higher Education and Economic Growth in Africa. Journal of Development Studies, Vol. 42, No. 3, pp.509-529. 